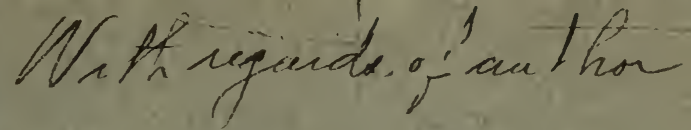

\section{SOME PLANT NAMES OF THE UTE INDIANS}

BY

\section{RALPH V. CHAMBERLIN}

Reprinted from the AmErican ANTHRopologist (N. s.), Vol. XI, No. 1, January-March, I909

Lancaster Pa., U. S. A.

The New Era Printing Company $x 909$ 



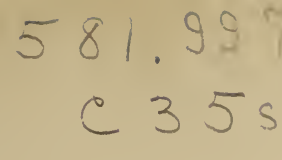

[Reprinted from the American Anthropologist, Vol. II, No. I, Jan.-March, I909.]

\section{SOME PLANT NAMES OF THE UTE INDIANS}

\section{By RALPH V. CHAMBERLIN}

W HILE among the Gosiute Indians in the spring of I 901 , the writer made the acquaintance of a Uinta Ute, named Tungaip, who had taken up a temporary abode there because of factional trouble among his own people such as to make his absence from them necessary to his safety. From him I secured the partial list of plant names herewith presented. The paper is now published in this preliminary and tentative form only because I do not foresee the opportunity to extend and elaborate or otherwise to better it, and in the hope that it may prove of some interest or aid to others. The names were obtained almost exclusively at the time mentioned from the now lamented Tungaip. With a few exceptions they have not been tested through others of his tribe, and some errors may therefore occur, especially in the case of the less familiar species.

The Ute proper held the richer game portions of Utah and adjacent parts, and were to a much greater degree hunters, and more warlike, than most of the relative tribes. Their dependence upon the vegetable kingdom was, naturally, less intimate than with such tribes as the desert-dwelling Gosiute, ${ }^{1}$ though no doubt a complete list of all kinds of serviceable plants among them would prove is large.

As compared with some related dialects, the language, among other things, appears to show a more frequent development of $z$ in place of $b$, especially in the nominal endings, and of $r$ in place of $t$ or $d$. For example, $-\hat{u} p$ is heard as $-\hat{u} v$, $-a v$, and $-\check{\imath} v$, depending on phonetic relations. The syllables $-g o-\hat{u} p$, and $-g i-\hat{u} p$, sometimes

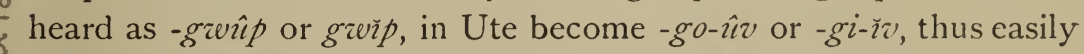
passing to gwriv or -gwin, in which form most commonly heard.

${ }^{1}$ This name is not derived etymologically from the name of chief Goship as is so often trsuggested. Goship was chief over a band of closely related Indians, but not over the Gosiute proper. The name is compounded from kitsip, or gitsip, meaning primarily $\oint$ 'ashes,' and hence, secondarily, 'parched or dry earth,' ' desert earth,' etc., and Ute ; cे. i. e., rendered freely, the name may be said to mean 'Desert Ute.'

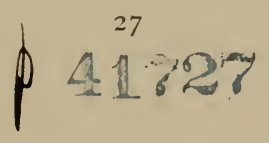


This is in line with a general phenomenon resulting from a strong tendency in the language toward an easy or gliding phonetic softness. The phenomenon as it appears to me is in the frequent suppression of syllables and letters, especially of vowels. In some cases vowels are heard very lightly and in others not at all. This results in the accumulation of consonants, of which illustrations are given among the examples below. There would seem to be a more frequent shifting of the primary accent to the second syllable, or, more rarely, to the third.

Examples of apparent condensation are :

kwi' ûv, oak, corresponds to Shoshoni and Gosiute kwi'ni up. pagrwai' îv, maple, corresponds to Shoshoni and Gosiute pa'gzvi ni up. $t u^{\prime} c a-g a r$, white, is frequently heard as tcar (cf. following word also). tsa'-kîm, white rabbit, cottontail, is probably derived from the preceding word $t u^{\prime} c a-g a r$, meaning white, and kîm, rabbit.

$k ' s a-k a-n a v$, or $k s a-n a v$, a species of willow, from $k u^{\prime}-t s i$-, ashes, hence gray, etc., in reference to the pubescent covering, or in some plant names to the dryness of habitat, and $k a-n a v$, general term for willow. The corresponding Shoshoni and Gosiute word is $k u u^{\prime} t s i-s i-o-p i$; $s i^{\prime}-o-p i$, or $s h i^{\prime}-o-p i$, in these languages corresponding to ka-nav.

$k a i-s i v$, Cornus or kinnikinnick, corresponds to Shoshoni $\ddot{a} \tilde{n}^{\prime} k a-s i b$.

Other cases similar to those above given occur in the subsequent list of plant names.

From such comparisons and study as I have made, the conclusion would seem justified that the primary roots of the Ute language are monosyllabic or largely so, as they are in the Gosiute. While a discussion of this subject cannot properly be entered upon here, some of the particles and combinations more frequently occurring in the plant names presented, more especially in the terminations, may be discussed briefly. Various examples of primary roots will be indicated in the analyses of words selected for illustration below : (I) $b, p, v$. - Indicating, in general, substance or material in nouns; in verbs occasionally indicating the production of a material thing; sometimes giving a participial or adjectival effect. Far most common as the noun ending, indicated in the following :

(2) $-\hat{u} p,-\hat{u} v .-A$ nominal ending added to verbs and indicating in 
general the substance or material involved; hence object or thing in general. For example :

o-pin-go-ûv(-gzenv), fence (of wood) : o-pi, wood, $+n$, adjectival ending, q. vid., $+g o$, verbal root meaning to enclose or surround, $+-\hat{u} v$.

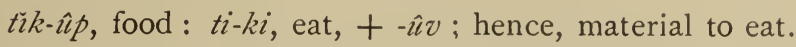

to-tsi-va-whuv, hair of head: to-tsi-in, head, + wu, thread or hairlike object, hence hair in general, $+-\hat{u} v$.

$k o-n o v$, sack: go, ko, root meaning to enclose or to surround, as indicated under the first example, + no, root meaning to carry, move, etc., $+-\hat{u} v$.

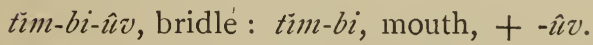

It is a common ending in plant names, as may be seen from an examination of the general list given later. In these names it has practically the meaning of "plant" in many cases. In some of these it is evidently the representative of $\dot{o}$-pi, wood, tree, or plant, rather than of $u p$ as in the case of sho-av, cottonwood, corresponding to Gosiute $s o^{\prime}-o-p i$.

(3) - $\hat{u} m p$. . A nominal ending indicating, in most cases, material or substance of service or use. In plant names it hence generally indicates the plant or plant product as useful for food. Its general use in this connection may be indicated by the Gosiute word for oats, $o$-at-ump, which appears to be simply the English word with -ump added.

The particle seems doubtless a development of $-\hat{\imath} m$ or $-m$, and $-\hat{\imath} p$; i. e. of the combination $-\hat{\imath} m-\hat{\imath} p$ or of $-m \hat{u} p$. U U $m$ or $-m$ following or added to a noun or noun group has a possessive or adjectival effect. By transliteration $-\hat{\imath} m p$ is derived. This may be seen, for example, in the Gosiute word for currant (the berry), which corresponds closely to the Ute, but is given because better known to me in its changes. This word is po-gon-îp, but quite as frequently is heard as po-gutmp. Hence it will be easily seen why - $\hat{\imath} m p$ is primarily added to other nouns, in contrast with the preceding ending, $-\hat{\imath} p$, which is primarily added to verbs, and also how, in most cases where it would primarily be used, the force would be to indicate material of service. The suffix is far most common in the combination indicated under (4). Examples : 
po-gitmp, currant (the berry). The name for the plant as a whole is po-gomp-iv, this being a good illustration of the point made previously that in plant names the ending $-\hat{\imath} v(-i v)$ has often the force of "plant."

$k u$-si-a-kimp, balsam-root: ku-tsi-, gray, ashen, in reference to the dense coat of hair on the plant, $+a-k a$, stalk, shoot, etc., $+-\hat{\imath} m p$. The young shoots, leaves, and their petioles, of this plant were formerly eaten.

to-împ, service-berries.

(4) -nimp. - A development of the preceding, consisting of that in combination with $n a$, a particle primarily added to a verb to indicate means or instrument, $-n a-\hat{\imath} m p$ becoming condensed to -mîmp, which in turn has become an integral suffix. It indicates instrument or means. Rarely it is used like $-\hat{\imath} m p$ or even - $\hat{\imath} p$ where euphony is obtained thereby. Examples :

$k a-r i-n \hat{u} m p$, chair or saddle: $k a-r i$, sit down, $+-n \hat{u} m p$.

tì-ki-nîmp, table: tì-ki, eat, + -nûmp.

ta-bi-nîmp, clock: ta-bi, sun, + -nîmp.

$t a^{n}$-gi-nîmp, stirrup : apparently from $t a$, particle indicating the foot or relation to it (nasalized, as is commonly so with vowels before $g$ or $k),+g i$, verbal particle indicating pressing or thrusting into, $+-n \hat{u} m p$.

(5) $t, d, r$. As an ending indicates quality, condition, or relation, and hence primarily is adjectival. It is a common adjective ending, such adjectives being sometimes used as nouns representing things having the qualities indicated. It is the ending in a number of plant names. Examples:

$a \tilde{n}$-kar, red. (And so with other names of colors. Cf. the Gosiute and Shoshoni ending in the equivalent $t$, in the combination -bit; as, añ-ka-bit, red, tu-o-bit, black, etc.)

to-kar, black.

$a t$, good.

$a-b a t$, great.

tin-zi-èr, hard.

na-ri-ènt, strong.

ku-bèr-ant, long, tall.

kwa-nar, kwa-na-ri, smelling, stinking. 
pu-ner, pu-ne-ri, looking, seeing, vision, adj. Cf. pu-ni-ke, see; pu-ne-ri-nimp, field-glass, i. e., 'vision instrument.'

kwi-o-kint, (I) circular, (2) circle: kzvi-o-kin, to move or make move in a circular path, etc., $+t$.

tì-ga-kint, (1) touching, bordering, (2) boundary-line: tĭ-ga-kĭn, to put against, to touch, to border, $+t$.

(6) $-t c,-t s,-d s$. - A common ending in the names of plants and animals, seeming quite generally to indicate an object living or regarded as living, a person or part of a living thing or person. The usage may be indicated by the word for mule, mu-rats. This seems to come from the English word mule, the $l$, which does not occur in Ute, being replaced by $r$ (cf. $k a-v a$, horse, apparently from Spanish caballo, the $l l$ here being wholly dropped) and ts added. It is a very common ending in plant names, perhaps that most frequent. Examples :

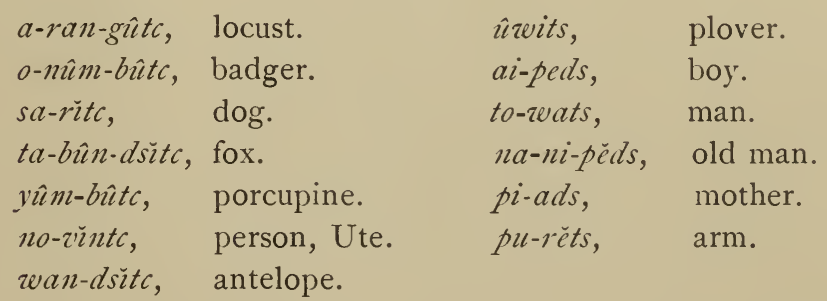

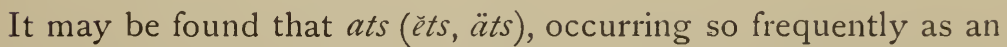
ending in Ute plant names, is in some cases to be regarded as integral (secondarily) and as alone the name or as having been the name of a particular plant, as is the case in Gosiute. Here it is applied to species of Amarantus, useful as food, and is made terminal in names of some plants thought to resemble this one in appearance or use. (7) $-m,-n,-\hat{\imath} m$. - Following a noun indicates possession or relation or gives the effect of an adjective to the noun to which added. Examples :

o-pim-go-tiv, fence: o-pi, wood, $+m,+g o,+\hat{\imath} v$. (Vid. ante under $-\hat{\imath} p$.)

$k a$-bam-si-ta-gwiv, horse medicine : $k a-b a, k a$-va, horse, $+m,+s \check{i}$ ta-gwiv, medicine.

sa-gruam-sì-ta-gwǐv, Abronia fragrans, which is used as a stomach medicine: sa-gwa-, stomach, $+m+$ š-ta-gwiv, medicine. 
tim-p̆m-tiv, Cystopteris fragilis: tim-pi, rock, $+\hat{u} v$, i. e. rock (loving) plant.

timp, timpi, mouth: ti, root meaning to strike or force into, cut into, and hence to bite; thus pertaining to a cutting object, $+m,+b i$, meaning part of a living body, etc. (Cf. the following, and also the combination -bitc, rare in Ute but common in related dialects.)

namp, nam-pi, foot: $n a$, thing beneath or supporting, bottom part, etc., $+m,+b i$, as in the preceding.

\section{List of Plants According to Scientific Names}

Abronia fragrans Nutt. Sand Puff. sa-gzam-š̈-ta-gzwiv: apparently sa-gzwa-, stomach, + si-ta-gwirv, medicine. The roots and flowers said to be used as a remedy in stomach and bowel trouble. The name is probably not specific, and will likely be found to be applied to other plants put to similar medicinal use.

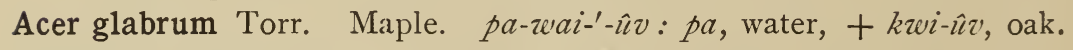
Achillea millefolium L. Yarrow. $i$-am'-š-ta-gwìv: $i$-a, wound, etc., $+m$, + sì-ta-gzur $r$, medicine. Applied externally on bruises, etc., and also used as a tea in cases of sickness.

Agropyrum repens Beauv. Blue-joint. ? wai-.

Allium bisceptrum Watson, acuminatum Hook. Onion. kün-ka. Bulbs and leaves eaten.

Amelanchier alnifolia Nutt. Service-berry. to-ĥump'. Berries were formerly an important food, being used in season and also preserved by drying for winter. Cf. Shoshoni and Gosiute $t i^{\prime \prime}-\hat{\imath} m p$.

Amsinckia tesselata. tu'-ka-rûmp. Cf. the Gosiute $k u-n i-r o-\hat{u} m p$.

Antennaria dimorpha Torr. and Gray, etc. Everlasting. tim'-pintsau-tuv: tim-pi, rock, $+n$, +tsau, submerge, cover under, etc., $+\hat{u} v ;$ i. e., apparently, rock-matting plant.

Arabis holboelli Hornem. Rock Cress. qta'-ko-mav.

Artemisia tridentata Nutt. Sage-brush. ma-av; ma-ap. Leaves used in decoction as medicine.

Asclepidiora decumbens Gray. Milkweed. sa-na'-ko-mav.

Aspidium filix-mas Schwartz. Wood Fern. kai"-ban-kum-bus : kai-ba, mountain, + n, +kim-hïa.

Astragalus iodanthus Watson. Buffalo Bean. tí-ž̆-p̆i-tcîm-av : probably from $t i$-wip, earth, $+t s u, t c u$, press, press over, etc., $+m,+$ $\hat{\imath} v$; i. e., likely meaning earth or ground-matting plant.

Balsamorrhiza sagittata Nutt. $k u-s i^{\prime}-a-k \hat{u} m p$ : ku-si-, from $k u$-tsip, 
ashes, hence meaning gray or whitish, in reference to the whitish covering of pubescence so conspicuous in this plant, $+a-k a$, shoot, etc., + -ump. The young shoots and leaves were formerly eaten, hence the name. The roots also were eaten to some extent.

Beckmannia erucæformis Host. Slough Grass. a-wat'-o-gzurv : a-zvat $+o$-gw̌̃.

Berberis repens Lindl. Oregon Grape ; Barberry. ksipp-o-a-ats.

Betula occidentalis Hook. Birch. ? pa-gwai'-üv.

Calochortus nuttallii Torr. and Gray. Sego. si'go. The bulbs of this plant were formerly much used as food. The Gosiute and Shoshoni name is identical.

Capsella bursa-pastoris Mœnch. Shepherd's Purse. mo'-těn-de-äts. Introduced into the region.

Capsella divaricata Walp. Shepherd's Purse (native). mo'-tèn-de-äts.

Carex jamesii Torr. Sedge. pi'-gzuîts (prob. $p a^{\prime}$-gzunts).

Castilleia parviflora Bong. Painted-cup. mo'-ten-dit. Root used as a medicine in bowel trouble.

Caulanthus hastatus Watson. añ-ga-ko-rimp.

Citrulus vulgaris (cultivated). Watermelon. shan-ti-kît.

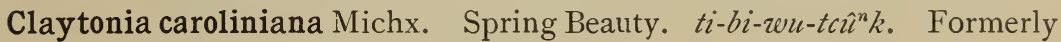
the bulbs were eaten extensively.

Collinsia parviflora Dougl. $m i^{\prime}-p \hat{\imath}^{n}-g a-s h \imath^{\prime \prime}-\check{e} t s$. Plant said to have been used externally as a remedy for sore flesh, like Gilia, q. vid.

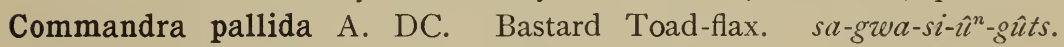
Roots used as a medicine in headache, etc.

Cornus stolonifera Michx. Kinnikinnick; Cornel. (I) kai'-sìv; (2)

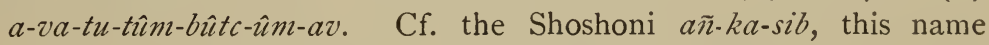
referring to the red bark ("red willow," probably). The Ute name seems to be condensed.

Cowania mexicana Don. Cliff Rose. pu-i'-tcîm-av.

Cymopteris longipes Watson. o-an-tĥv. Leaves formerly boiled and eaten as food. It seems probable that the Shoshoni name for this plant, to $i^{\prime}-y a n$-dîp (toi'ya-bi, mountain, $+n$, + dîp), preserves most nearly the original form, and that the Ute $o$-an-tîv and the Gosiute an- $d s \hat{u} p^{\prime}$ are abbreviated.

Cystopteris fragilis Bernh. Fern. tim-p̌m-lîv: tim-pi, rock, $+m,+\hat{u} \imath$. Delphinium menziesii DC. and bicolor Nutt. Larkspur. sa-gze-rint. Draba nemorosa L. Whitlow Grass. kus-pa-sen-di-ät.

Eleocharis palustris R. Br. Spike-rush. $p a-o^{n}-g a-d a-p i n-t i d: p a-o$, referring to water, $+g a$-da-pin-tid. 
Elymus canadensis L. Lyme Grass. o-do-rîm-biv. Seeds formerly gathered as food.

Eragrostis purshii Schrad. kaib'-o-gwiv: kai-ba, mountain, +o-gwiv. Erigeron canus Gray. Fleabane. ? sa-gîm-š̆-ta-gwiv.

Eriogonum ovalifolium Nutt. Silver-plant. k'sîm-sêd-au-ge-èts : prob-

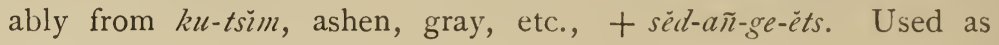
medicine.

Equisetum arvense L. Horsetail. (a) fertile stems, tu-ko-wrîts; (b). sterile stems, to-tsi-zenits.

Equisetum lævigatum Braun. Scouring-rush. $y a-a^{\prime}$-ti-nûmp. Likely from $y a-a-g i$, cry, call out, etc., $+t$, $+-n \hat{u} m p$, instrument, etc., in reference to its use by children as whistles.

Eragrostis purshii Schrad. kaib'-o-gziv .

Erodium cicutarium L'her. Storks-bill; Alfilaria. $p a^{\prime}$-bo-i-äts.

Erysimum asperum DC. $s a^{\prime}-g o-a^{\prime \prime}-\operatorname{sint}$.

Ferula multifida Gray. to-tûv. The root furnishes one of the medicines most highly valued among this and related peoples. It is especially applied externally upon wounds and bruises, being first reduced to a pulp between stones or in a mortar. It is also used for distemper in horses; for this purpose it is burned in a pan held beneath the horse's nose.

Fritillaria atropurpurea Nutt. Tiger Lily; Brown Lily. kaı́-rîm-sìta-gwiv. The bulbs and roots used as medicine in the form of a decoction. It is said to be taken but sparingly because in larger quantities it is regarded as dangerously poisonous.

Fritillaria pudica Spreng. Buttercup; Yellow Bell. pim'-i-kwi-èts. Formerly the bulbs were used as food.

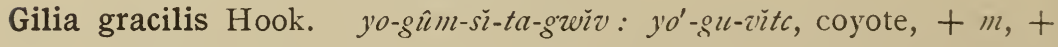
si-ta-grviz, medicine. Used as a poultice on bruised or sore leg. In this connection cf. the Shosnoni name for this little Gilia, so abundant in the region: $i$-am-b̌p, the first part of which would seem to refer to wound.

Glaux maritima L. Sea-milkwort. tsû̀n'-a-na-dì-èts.

Grass (general term). $o^{\prime}$-wiv.

Grayia polygaloides Hook and Arn. Shad Scale. ? sa'-mîv.

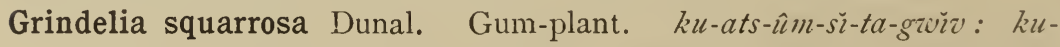
ats $+\check{u} m$, possessive, + si-ta-gwiz, medicine. Said to be used as a cough medicine. Cf. Senecio.

Guttierezia euthamiæ Torr. and Gray. Lesser Rabbit Brush ; Torchweed. shpiump. 
Hedysarum mackenzii Richard. kai-va-ma-mî-tca-kwîv; mo'-těm-beitch: kai'va, mountain, $+m$, $+m u$-tca-kwuv. Roots said to be used as medicine.

Hydrophyllum capitatum. Waterleaf. o-at'ěm-bi-ěts.

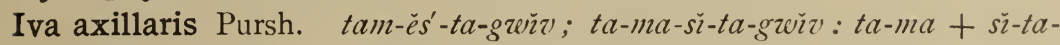
gzŭ̃ medicine. Occasionally used as medicine.

Juncus balticus Deth. Bog-Rush. paiı-wît. Corresponding to the Shoshoni and Gosiute name for the same plant, $p a^{\prime} h w a p$, also heard more fully as $p a^{\prime}-\hat{\imath} m-\grave{u} p: p a-\hat{u} m$, aquatic, $+\grave{u} p$.

Juniperus californica var. utahensis. Cedar. wap. The name is probably from wa-ap, meaning, in some dialects (e. g., Shoshoni), to burn, the reference probably being to the use of the bark, etc., in making slow-match and for kindling purposes.

Krynitzkia sericea Gray. $y u^{\prime}$-bi-shad-ûmp. Root used as stomach medicine.

Lathyrus ornatus Nutt. Everlasting Pea. sa-gzu'-sa-int.

Lepidium intermedium Gray. Pepper-grass. sau'-ga-mi-ants.

Lepidium sativum. Pepper-grass. $w a^{\prime}$-to-ma-si $\%$.

Lithospermum pilosum Nutt. Gromwell. tsît-kûp. Roots used as medicine in form of decoction; diuretic in action. I have seen it used by an old couple for this purpose.

Lonicera utahensis Watson. Woodbine. te-èd-kav: te-a,ti-a, deer, + $k a v$. Cf. the Gosiute name for this plant: parri-ěn-dí-kîp, meaning elk food.

? Malvastrum munroanum Gray. False Mallow. sa-gzûnn-na-ga-ats. Matricaria discoidea DC. May-apple. (ma)-mo-a-na-nûmp. Used as a medicine.

Orogenia linearifolia Watson. pin-'ka-pai-äts.

Pachystima myrsinites Raf. Box. te-ě-kav. Cf. Lonicera.

Pentstemon glaber Pursh. Beard-tongue. mî-tcèm-bi-a.

Phacelia menziesii Torr. ? (ma)-mî̀'-tèm-bi-a.

Phlox longifolia Nutt. Phlox; Sweet William. (mo)-mu-kwi-èts.

Pinus mojophylla (nuts of). Pine-nuts. ti-va.

Populus angustifolia James. Cottonwood. sho-av: sho $+a v$, from $o$-pi, wood. Cf. Gosiute so-o-pi.

Potentilla anserina L. Five finger. qte'-än-giv.

Pteris aquilina L. Brachen. kai-ban-kĭm-bìs: kai-ba, mountain, + $n,+k \grave{\imath} m-b \grave{s}$. See also Aspidium filix-mas Schwartz.

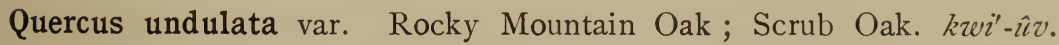
The Gosiute form is kwi-ni-hip, and is sometimes heard as ku-ni-ripp. 
Ranunculus aquatilis L. var. Buttercup. pai'-a-pu-èts.

Ranunculus cymbalaria Pursh. Buttercup. pau-îs-a-nau-ga-ant.

Rhus aromatica Ait. var. trilobata Gray. Sumach; Squaw-berry. mo-tam-li-äts. The berries, are eaten.

Ribes aureum Pursh. Buffalo or Missouri Currant. po-gomp'-iv : po-gomp, currant (the berry), $+\hat{\imath} v$. Berries used as food.

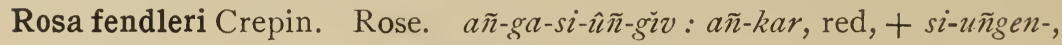
stem, etc., $+u v$. Berries sometimes eaten.

Salix amygdaloides Anders., lasiandra Benth., var, and cordata Muhl. k'sa-nav; k'sa-ka-nav: ksa, probably shortened from $k u^{\prime}-t s i$-, ashen, grayish, etc., $+k a-n a v^{\prime}$, willow. Used in basketry, etc.

Salix flavescens Nutt. Willow. ta-ma-nûmp-in-av; ta-ma-nûmp-in$k a-n a v$.

Salix longifolia Muhl. Willow. ka-nav'. Used in basketry, etc.

Scirpus validus Vahl. Bulrush. t'su-saip. Lower, tender portions eaten.

Senecio sp. Groundsel. ko-ats-ěm-š̆-ta-gzwiv : ko-ats, + èm, possessive, + si-ta-gzinz. Used as medicine. Cf. Grindelia.

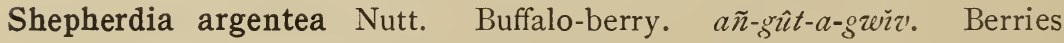
formerly used as food to some extent.

Shepherdia canadensis Nutt. ta-ma-nûmp.

Sisymbrium canescens Nutt. Hedge Mustard. po-é-tcèm-ěn. Used as medicine.

Smilacina amplexicaulis Nutt. False Solomon's Seal. yo-grvo'tama-nûmp: yo-go-rìtc, coyote, +ta-ma-nûmp. Cf. the Gosiute $i$-tcu-pain-po-go-nîp, from $i$-tcu-pa, coyote, $+n$, possessive, + po-gonûp, berry, i. e., 'coyote berry.'

Solanum tuberosum (cultivated). Potato tsiñ. Transferred from the name of a native plant.

Streptanthus cordatus Nutt. o-nûn-ga-ats.

Taraxicum officinale Weber. Dandelion. (mo)-mûn'-ti-ad-qsîp.

Leaves formerly used as food. Cf. the Shoshoni mî-tca-gi-a.

Tellima parviflora Hook. añ-gai-ya-ga-ti-nûmp.

Trifolium, general term. Clover. mo'-pi-änts; mû́-pi-änts.

Trifolium pratense L. (introduced). Red Clover. ?sa-gwa-inn-di-îtp. Triglochin maritimum L. Arrow-grass. $p a^{\prime}$-sau-wa-dint.

Troximon sp. añ-'ka-pi-sa-wats. Leaves formerly eaten, like the dandelion. 
Valerianella congesta. $\ddot{a} \tilde{n}-g o-i-e ̈ n t s$.

Veronica aggerata Speedwell. pu'-i-ants.

Vicia americana Muhl. Vetch. ka-na-te'-änts; pu-i-pi-îm-av : pu-i-pi, blue, $+i m m,+a v$. The second name refers to the blue or purplish flower and is probably general.

Viola beckwithii. Wild Pansy. ka-bam-si-ta-gzinv: ka-ba, horse, $+m$, $+s \breve{\imath}^{\prime}$-ta-gwr̃ , medicine.

Viola canina L. var. sylvestris Regel. Violet. sau'-o-ma-änts.

Viola cucullata Ait. Violet. sau-ěd-řn-do-èts. Roots used as medicine. Zygadenus nuttallii Gray. Poison Sego. ta-bä'-si-gziv: $t a^{\prime}-b i$, sun, $+s i-g o,+i v$, 'sun sego.' The bulbs of this plant are poison, hence the common name as given above. The sego proper is Calochortus nuttallii.

\section{Alphabetical List of Plants According to Ute Names}

añ-gai-ya-ga-ti-nûmp. Tellima parviflora Hook.

$a \tilde{n}$-ga-ko-rimp. Caulanthus hastatus Watson. Rose.

$a \tilde{n}$-ga-si-tîn-giv. Rosa fendleri Crepin. Buffalo-berry.

añ-go-i-ènts. Valerianella congesta.

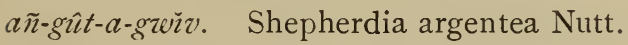

$a \tilde{n}^{\prime}-k a-p i-s a-w a t s$. Troximon sp.

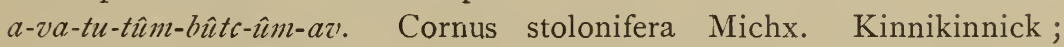

Cornel. Cf. kaı'siv.

$a$-wat'-o-gwiv. Beckmannia erucæformis Host. Slough Grass.

$i$-am'-š́-ta-gzuiv. Achillea millefolium L. Yarrow.

$k a-b a m-s \grave{i}-t a-g z i v v . \quad$ Viola beckwithii. Wild Pansy.

kai'-ban-kim-bis. Aspidium filix-mas Schwartz, Pteris aquilina L. Wood fern; Bracken.

kaib-o-gzinv. Eragrostis purshii Schrad.

kai-rîm-š̈-ta-gzǐz'. Fritillaria atropurpurea Nutt. Tiger Lily ; Brown lily.

kai-va-ma-mî-tca-kwîv. Hedysarum mackenzii Richard. Vetch. kaib-o-gzǐv. Eragrostis purshii. Kinnikinnick; Cornel.

kai-sǐ . Cornus stolonifera Michx. Willow.

$k a-n a-t e^{\prime}-\ddot{a} n t s . \quad$ Vicia americana Muhl.

$k a-n a v^{\prime}$. Salix longifolia Muhl.

ko-ats-ěm-š́-ta-gzuiv. Senecio sp.

k'sa-ka-nav; ksa-nav. Salix amygdaloides Anders; Salix lasiandra

Benth. var.; Salix cordata Muhl.

ksip-o-a-ats. Berberis repens Lindl. Oregon Grape; Barberry. 
k'sûm-sed-an-ge-èts. Eriogonum ovalifolium Nutt. Silver Plant.

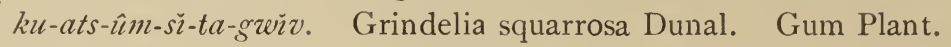
kiiñ-ka. Allium bisceptrum Watson; Allium acuminatum Hook. Onion. ku-si"-a kûmp. Balsamorrhiza sagittata Nutt. Balsam root; Arrow root. kus-pa-sén-di-ät. Draba nemorosa L. Whitlow Grass.

kwei'-û̀?. Quercus undulata Torr. var. Rocky Mountain Oak; Scrub Oak.

$m a-a b$; ma-av. Artemisia tridentata Nutt. Sage-brush.

? (ma)-mâ-tèm-bi-a. Phacelia menziesii Torr.

$m i^{\prime}-p \hat{\imath}^{n}$-ga-shi"ętts. Collinsia parviflora Dougl.

(ma)-mo-a-na-nûmp. Matricaria discoidea DC. May Apple. mo-mu'-knei-ěts. Phlox longifolia Nutt. Phlox; Sweet William. mo-pi-änts. Various species of Trifolium. Clover.

mo-tam-bi-äts. Rhus aromatica Ait. var. trilobata Gray. Sumach; squaw-berry.

mo-tën-de-äts. Capsella bursa-pastoris Mœnch.; Capsella divaricata Walp. Shepherd's purse.

mo'-ten-aüt. Castilleia parviflora Bong. Painted-cup. (mo)-mûn'-ki-ad-ksûp. Taraxacum officinale Weber. Dandelion. $m \hat{\iota}^{\prime}$-tcèm-bi-a. Phacelia menziesii Torr.

$o^{\prime}$-ant-ûv. Cymopteris longipes Watson.

$o$-at'-èm-bi-ëts. Hydrophyllum capitatum. Water leaf.

o-do-rûm-biv. Elymus canadensis L. Lyme Grass.

o-nûn-ga-ats. Streptanthus cordatus Nutt.

o-ziv. Grass (in general).

$p a^{\prime}$-bo-i-äts. Erodium cicutarium L'her. Stork's Bill ; Alfilaria.

? pa-grwai'-tû. Betula occidentalis Hook. Birch.

pai'-a-pu-i-ëts. Ranunculus aquatilis L. var. Buttercup.

$p a-o^{n}-g a-d a-p i n-t z i d . \quad$ Eleocharis palustris R. Br. Spike-rush.

pa'-sau-zera-dint. Triglochin maritimum L. Arrow Grass.

pau-tis-a-nau-ga-ant. Ranunculus cymbalaria Pursh. Buttercup. pau-wûv. Juncus balticus Deth. Bog-rush.

$p a-w a i^{\prime}-\hat{u} v . \quad$ Acer glabrum Torr. (see also pa-gwai'-uv). Maple.

pi-gzents. Carex Jamesii Torr. Sedge.

pĭm'-i-kwi-èts. Fritillaria pudica Spreng. Yellow Bell; Buttercup. pin'-ka-pai-äts. Orogenia linearifolia Watson. po-é-tcèm-ěn. Sisymbrium canescens Nutt. Hedge Mustard. po-gomp'-iv. Ribes aureum Pursh. Buffalo or Missouri Currant ; Currant.

$p u^{\prime}$-i-ants. Veronica aggerata. Speedwell. 
pu-i-pi-ûm-av. Vicia americana Muhl. Vetch.

$p u-i^{\prime}-t c \hat{u} m-a v$. Cowania mexicana Don. Cliff Rose.

$q t a^{\prime}-k o-m a v$. Arabis holboelli Hornem. Rock Cress.

$q t e^{\prime}-\ddot{a} \tilde{n}$-ğv. Potentilla anserina L. Five Finger.

$s a^{\prime}-g o-a^{\prime \prime}-$ sint. Erysimum asperum DC.

? sa-gûm-sì-ta-gzurz. Erigeron canus Gray. Fleabane.

sa-gza-ǐn-di-ûp. ? Trifolium pratense L. ? Red Clover.

sa-gzoan-sï-ta-gwĩv. Abronia fragrans Nutt. Sand Puff.

sa-gzva-rinnt. Delphinium menziesii DC.; Delphinium bicolor Nutt.

Larkspur.

sa-grwa'sa-int. Lathyrus ornatus Nutt. Everlasting pea.

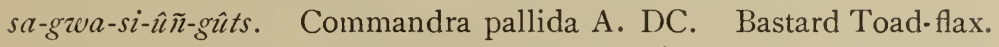

sa-gzûnn-na-ga-ats. ? Malvastrum munroanum Gray. ? False Mallow.

sa'-mîv. ? Grayia polygaloides Hook and Arn. ? Shad Scale.

$s a-n a^{\prime}-k o-m a v$. Asclepidiora decumbens Gray. Milkweed.

sau-êd-in-do-èts. Viola cucullata Ait. Violet.

sau-ga-mi-ants. Lepidium intermedium Gray. Pepper-grass.

sau'-o-ma-änts. Viola canina L. var. sylvestris Regel. Violet.

shan-ti-kît. Citrulus vulgaris. Watermelon.

sho-av. Populus angustifolia James. Cottonwood.

shpûmp. Guttierezia euthamiae Torr. and Gray. Rabbit-brush; Torchweed.

si-go Calochortus nuttallii Torr. and Gray. Sego.

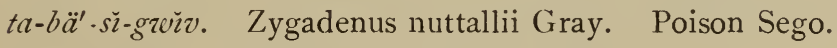

ta-ma-nûmp. Shepherdia canadensis Nutt.

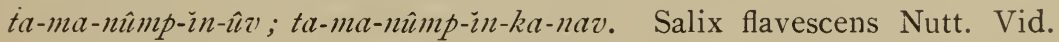

sub. Salix in preceding list. Willow.

ta-ma-si-ta-gwirv; ta-mes'-ta-gzurz. Iva axillaris Pursh.

te-éd-kav. Lonicera utahensis. IVoodbine.

te-é-kav. Pachystima myrsinites Raf. Box.

ti-bi-zou-tck${ }^{n}$. Claytonia caroliniana Michx. Spring-beauty.

timn'-pin-tsau--ûv. Antennaria dimorpha Torr. and Gray. Everlasting. tïm-pǐk-l̂̀v. Cystoperis fragilis Bernh. Fern.

ti-va. Nuts of Pinus monophylla Torr. Pine-nuts.

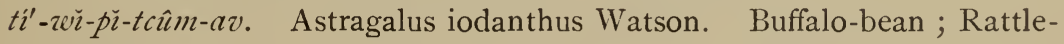
weed.

to-tsi-wn̂ts. Equisetum arvense L., sterile stems. Horsetail.

to-tîv. Ferula multifida Gray.

to-împ'. Amelanchier alnifolia Nutt. Service-berry.

tsiñ. Solanum tuberosum. Potato. 
tsûn'-a-na-di-ěts. Glaux maritima L. Sea milkwort.

t'su-saip. Scirpus validus Vahl. Bulrush.

tsît-kîp. Lithospermum pilosum Nutt. Gromwell.

tí-ka-rûmp. Amsinckia tesselata.

tu-ko-zerits. Equisetum arvense L., fertile stems. Horsetail.

wai. ? Agropyrum repens Beauv. Blue-joint grass.

wap. Juniperus californica var. utahensis. Cedar juniper.

$w a^{\prime}$-to-ma-siv. Lepidium sativum. Pepper-grass.

$y a-a^{\prime}$-ti-nûmp. Equisetum laevigatum Braun. Scouring Rush.

yo-gûm-š̀-ta-gzwǐv. Gilia gracilis Hook. Gilia.

yo-gzwo'-ta-ma-nûmp. Smilacina amplexicaulis. Nutt. False Solomon's Seal.

$y u^{\prime}$-bi-shad-ûmp. Krynitzkia sericea Gray.

Provo, UTAH 



